\title{
Writing Book Reviews for the Journal Of Range Management and Rangelands
}

\author{
DAVID L. SCARNECCHIA
}

Author is Associate Professor, Department of Natural Resource Sciences, Washington State University, Pullman, Wash., and Book Review Editor, Journal of Range Management and Rangelands.

\begin{abstract}
Effective, analytical reviews of recently published books inform readers of their essential content, and evaluate and communicate the value of their content to professional disciplines and the reading public. Such book reviews are widely read contributions to the Society for Range Management's publications, the Journal of Range Management and Rangelands, and are important elements of evaluation and communication within the Society. This paper is designed to assist writers in developing book reviews for the Journal of Range Management and Rangelands. Much of its analysis is relevant to book reviews for other publications. It begins with preliminary considerations for prospective authors. The functions of a book review are explained. Important considerations concerning reading the book are examined. The paper emphasizes the importance of finding a theme for a review. The common parts of a written review, i.e., the introduction, description of content, analysis and evaluation, and closing are considered individually. The paper then examines aspects of editing a review, and addresses some matters of style in writing. It concludes with a brief discussion of the importance of synthesis in developing an effective book review.
\end{abstract}

Key Words: literary style, technical writing, editing, range management science, synthesis, art

The $17^{\text {th }}$ Century Dutch artist Jan Vermeer is credited with fewer than 40 paintings, many variations or parts of a single composition. That such an artist could be recognized as a master reminds us that even high art often begins with refined craft involving effective combinations and subtle variations of basic elements. If skilled writing is a mysterious synergistic art, it is nonetheless based on, and at least partly decipherable as, a craft of literary combinations and variations.

This paper examines the process of crafting a book review for the Journal of Range Management and Rangelands. Reviews of books inform readers of their contents, and evaluate and communicate the value their contents to professional disciplines and the reading public. Such reviews are widely read contributions to the Society for Range Management's 2 major publications, and are important elements of professional evaluation and communication within the Society. This paper is designed as a guide to encourage and assist future authors in preparing written reviews of technical, semi-technical, or popular books. It has been developed from notes of 2 presentations during writing workshops for

Manuscript accepted 19 Nov. 03.

\section{Resumen}

Las revisiones analíticas efectivas de los libros publicados recientemente informan a los lectores de su contenido esencial y evalúan y comunican el valor de su contenido a los profesionales de las disciplinas y al publico lector en general. Tales revisiones de libros son contribuciones ampliamente leídas en las publicaciones de la Sociedad de Manejo de Pastizales y son elementos importantes de evaluación y comunicación dentro de la Sociedad. Este articulo de opinión esta diseñado para ayudar a los escritores a desarrollar revisiones de libros para las revistas Journal of Range Management y Rangelands. Mucho de su análisis es relevante para los revisores de libros de otras publicaciones. Inicia con consideraciones preliminares para los prospectos de autor. Las funciones de una revisión de libro son explicadas. Se examinan consideraciones importantes respecto a la lectura del libro. Este articulo enfatiza la importancia de encontrar un tema para una revisión. Las partes comunes de una revisión escrita, esto es, introducción, descripción del contenido, análisis y evaluación y el cierre de la revisión son consideradas individualmente. Entonces el artículo examina los aspectos de editar una revisión y aborda algunos aspectos del estilo de escritura. Concluye con una discusión breve de la importancia de la síntesis en desarrollar una revisión de libro efectiva.

the Journal of Range Management and Rangelands at the Winter Meeting of the Society for Range Management in Kansas City, Missouri, 14-18 Feb. 2002.

This paper is clearly not a comprehensive treatment of the subject of book reviews. More exhaustive treatments have long been available (e.g., Drewry 1945), and more recent, abbreviated writings (e.g., Thomson 1991) are in print. Some elements in the sections on writing and style are derived directly, indirectly, or inevitably from the excellent book by Strunk and White (1959). But most of the paper's content is not derived from published literature; instead, most is derived from 13 years of professional experience as Book Review Editor of the Journal of Range Management, and more recently, Rangelands, and as an author of more than 70 book reviews in those publications.

\section{Preliminaries}

Book reviews can be submitted to the Journal of Range Management or Rangelands by anyone. Before developing a review for either publication, contact the Book Review Editor to ensure that the book is suitable for review. In view of the diversity of membership in the Society for Range Management, and the wide philosophical scope of range management science, the range 
of topics for review books is panoramic. The apparent relevance and potential interest of a book to readers of the Journal of Range Management or Rangelands are the guiding editorial criteria. The book should be recently published, certainly within the past 18 months, preferably within the past year, ideally within the past several weeks or months. With exceptions, books that are more technical are more suitable for the Journal of Range Management, while less technical ones are preferred for Rangelands. If a book is particularly interesting or controversial, 2 contrasting reviews of the book may be published. New titles can be found in bookstores, at book sites on the Internet, and in libraries. In many cases, the book review editor can provide a review copy of a chosen book. You may find it easier to review a book on a subject in which you have expertise or experience so that you will be able to bring additional, external elements to the review.

Reviewing a book provides at least 2 compensations beyond the review copy of the book that the book review editor may provide. Your review may be expeditiously published and contribute to your professional development. Also, reviewing a book can provide considerable satisfaction as a creative exercise, and as a scholarly or disciplinary contribution.

\section{Functions of a Book Review}

Reviewers preoccupied with a book review as a critique sometimes overlook the review's other functions. One function of a book review is to inform. First, a review makes the reader aware that a book has been published. The proliferation of books published in recent years has effectively increased the value of one aspect of this function by bringing attention to books that might otherwise be lost in the plethora of competing titles. A review should further inform the reader about various aspects of a book including its objectives, technical content, format, and presentation. In technical books of the kind often reviewed in the Journal of Range Management, description of the technical content is especially relevant.

Evaluation, ie., the provsion of a critique, is a second function of a review. Evaluation can be detailed or superficial depending on the reviewer's expertise and objectives. Most readers consider evaluation as an essential feature of an effective review, but evaluation may in some cases be a minor component of a review.

A third function of reviews, the one most often neglected in reviews of techni- cal books in scientific journals, is effective communication. A book review should be interesting to read. Even if written by a scientist, a review should be more readable than a scientific paper. Many book reviews currently published in scientific journals are arid reading. High readability and high literary quality are important objectives in developing book reviews for the Journal of Range Management and Rangelands.

\section{About the Reading}

Prospective authors of reviews have occasionally asked: Do I need to read the book? Yes, you do; and no, you don't. If the book is a large reference with no real text, or a text that is unreadable, you probably will not read the entire book. Some modern books are essentially annotated computer printouts of technical detail not designed for reading. A large, technical, edited book with numerous text contributors may be too time-consuming for you to read in its entirety, or maybe only parts of it are of interest to you; you may choose to read and review parts of it. Authored, rather than edited books should generally be read in their entirety, certainly if you will be including significant analysis and evaluation of them. Avoid criticism of parts of a book if you are uncertain of their context.

Make notes as you read. Note particular passages, features or omissions that you might use in writing your review.

Find a theme for your review. Interpret the word theme broadly here to mean the idea that you make the essence of your review, and often the idea that you see as the essence of the book. Your theme may be an obvious thesis, or proposition, that drives your review. In other cases, depending on your objectives, it may be a subtle thesis, or be less than a thesis -sometimes little more than a word, a phrase, a tone, some thread to weave through your review.

As you read, stay as open-minded as possible as you look for a theme for your review. Searching for a theme is like being an investigator looking through a desk drawer for a clue-you don't know what you are looking for, but you want to know it when you see it. Sometimes the theme of your review will be the cumulative message of the book. It may be found in one chapter, in one paragraph, in one sentence, in one word. The theme of your review may be something that is absentsomething omitted from the book. Be alert and find a theme; it will make your review easier to write, and make it better.

\section{About the Writing}

Find a theme. If you were unsuccessful in identifying a theme for your review during the reading of the book, try again to find one before you begin writing. Without a theme, your review will be more linear and relational than circular and artistic.

Develop an outline from the notes you made while reading the book. The outline need not be formal, only functional.

Begin writing the review. You may not want to begin with the introduction. Avoid writer's block by writing the parts of the review you are most comfortable with, or are sure of. If you know what you are going to say, consider writing the last paragraph first, so that subsequent writing can be directed toward your ending.

Most reviews can be divided into 5 parts. The citation is the first element of the review. It should include the title, authors, year published, publisher, number of pages, price, kind of binding, and ISBN number. The format for citations can be seen in reviews in recent issues of the Journal of Range Management or Rangelands.

The introduction may be the most important part of the book review. Try to mention the title and author in the introduction, but the other information in the citation need not be repeated. The opening sentence of your review should be attractive; it should encourage the reader to continue reading. If you begin your review with This book is, you have wasted an opportunity.

In the introduction, the reviewer has the most creative freedom. Use it to establish tone. Some reviewers want to hurry through the introductory paragraph to get on with the review. Resist the impatience. Give yourself something to work with. Exploit the freedom by introducing background information, either from within the book, or from outside. Information from within the book may take the form of the authors' objectives, or relevant passages from the book. Information from outside may consist of relevant anecdotes, technical information, personal experiences, incisive quotations -- anything relevant that will help you in developing your review. Have a purpose for every idea introduced here.

In short, use the introduction to introduce elements that you want to use later. As a short piece of writing, a well-written book review will often be more interesting and have greater unity if it has circularity rather than linearity. One way to achieve circularity is to refer in later paragraphs to 
elements mentioned previously, especially to elements in the introduction. A wellplanned introduction is one that is directed toward your goals as author of the review. It should prepare the reader, both technically and psychologically, for the points you want to make by the time you've finished.

The description of content is the most challenging part of the review to make interesting. Mostly informational, it can consist of a block of sentences or paragraphs describing the content of the book. Here you can mention features of the book in addition to its text: its format, figures, tables, appendices, indexes, glossaries, cited literature, etc. The description of content may be interspersed with some analysis and evaluation, or may be a more or less continuous section. In the latter case, variation in syntax and wording can avoid monotony in your description of content. In the former case, monotony is less likely, but fragmentation of your review in pursuit of secondary points of interest is more likely.

In either case, a distinct section of analysis and evaluation will usually follow the description of content. Here you can analyze the technical content, literary merit, and social value of the book. Be as objective as possible. $\mathrm{Be}$ as forthright as sound judgment permits. You may want to discuss both the merits and inadequacies of the book, but if one class overwhelms the other, evenhandedness may hedge your critique.

Avoid overstated or destructive criticism. If you have strong adverse judgments about a book, you will be more effective if you express them with subtlety, with finesse, invoking elements of understatement or wit (not humor). If you express negative judgments, be sure your review is especially well written.

If you choose to indulge in creativity in the form of literary color (i.e., subtle allusions, metaphorical references, plays on words, etc.), the analysis and evaluation section is a good place to bury such elements for attentive readers to unearth. Such amusements can add texture to your writing, but should contribute to, not distract from, your theme.

The closing of your book review is the final impression that you leave the reader, and, for that matter, the book's author(s). In your closing, avoid repeating or summarizing points made previously. Do not introduce entirely new major points. Avoid using non sequiturs. For example, if your comments about a book have been consistently favorable throughout your review, do not insert a negative comment out of context in the last sentence. Such injudicious non sequiturs seem neurotic, seem destructive, and are self-destructive; you will not only discredit your previous writing, but will undermine your credibility, certainly as a writer, and likely as a reviewer. To create circularity in your review, you may refer to elements mentioned in the introduction, or during the analysis and evaluation. You have a chance to be creative in closing if you have made preparations in the introduction and analysis and evaluation sections. If you have not made adequate preparations, literary techniques discussed previously, if used here, will likely seem unwarranted or gimmicky. In any case, end with a strong closing sentence.

If you cite other literature in your review, internalize the citations in parentheses within the text. Cite literature sparingly, and only with good reason.

Except in special cases, do not bother telling the reader whether the book is worth its price. Value $=$ quality/price. You will have given the price in your opening citation. If you have written an informative review, the reader will be able to calculate value.

\section{Editing your Review}

Once you have finished writing it, let your review cool for at least 2 days before you edit it. More time is better. The fevered mental state often needed in writing a good review may be a liability in editing it. Let your review cool long enough for your mind to unwind, so that you can examine your review not as an impassioned writer, but as an interested, educated, but dispassionate reader.

If you are a good writer, you may be as effective an editor as your book review editor. Your superior familiarity with the book and greater understanding of your review's objectives will compensate if you have deficiencies in technical editorial skill. So do not rely excessively on your editor, especially in matters of literary style. Check your writing for clarity of communication from the reader's viewpoint. Examine transitions between sentences and paragraphs. Check syntax for parallel construction. Omit needless words and overstatement. Use a dictionary to evaluate any questionable usages of words. If a sentence reads badly, rewrite it. If the clarity of a sentence is marginal, rewrite it; it will look even worse to you when it is published. Give special care to your opening and closing sentences and paragraphs. Edit meticulously and repeatedly to ensure quality.

\section{Literary Style}

Writers with little experience in popular or technical writing may have concerns about whether their writing style is appropriate, or sufficiently personalized. Aspiring technical writers may want their writing to sound scientific, and may seek this effect through lofty verbiage or specialized jargon. While style is personal and creative, effective words, simply arranged, have considerable inherent style. Minimalist writing is potent. It conveys confidence, clarity of thought, and it confers to the reader confidence in you as a writer. Simplicity in writing acknowledges that the ultimate goal of writing is communication, not self-aggrandizement. But whether your style is minimalist or more elaborate, the following principles will apply.

Avoid trite language. For example, saying that a book is a good read significantly increases the probability that your review will not be.

Avoid adverbs as modifiers of adjectives. Linguistic leeches like very, extremely, dramatically, etc., sap energy from writing.

Write in the active voice.

Minimize noun adjuncts, i.e., strings of modifying nouns. Show the reader the quality of both your writing and your mercy; use some prepositions.

Do not frame your syntax in weak introductory clauses. Avoid introductory constructions like There is, There are, and It is + (adj. or $a d v$.). Where you write such constructions, a better sentence is at hand.

To improve clarity, aim for precise transitional linkages between sentences and paragraphs. Do not be reluctant to repeat words in successive sentences to achieve effective transitions.

Without violating standards of good usage, use words in creative or energetic ways, but only if doing so is effective and does not cause confusion.

Consider using creative similes, metaphors, and well-chosen quotations to create imagery and facilitate communication. Metaphorical language can make your writing more interesting, and can be effective in engaging readers' other senses. Assiduously avoid trite metaphors.

Be slightly poetic. Consider use of alliteration or assonance for color, rhyme and effectiveness, but do not overdo either.

Seek rhythm in your writing to establish the tone of your review, to improve its readability, and to appeal to your reader's 
auditory sense. Rhythm begins within sentences with simple syntax and parallel construction. It can be enhanced by effective arrangement of sentences within paragraphs. Partial or tactical repetition of syntax can enhance rhythm. To improve readability, vary rhythm periodically by varying length of sentences and paragraphs.

$\mathrm{Be}$ creative. Surprise is the essence of much interesting writing. Do not telegraph your every intention as a writer. Make the reader at ease with your writing, but everso-slightly off balance, and interested in your next word or sentence.

Aim for synergy. Visualize and develop your review as a unified circular synthesis, not as a relational, linear string of sentences. To be well crafted, a review should integrate disparate elements. Aspects of the book, your experiences and knowledge, your literary skills, your personality, your awareness of your readerthese elements and more should contribute to the synthesis of your review. Adherence to the techniques described in this viewpoint should help in crafting your book review for the Journal of Range Management or Rangelands. Whether or not your review rises to the level of art will depend on the effectiveness of your synthesis.

Artistic writing, like much art, begins with a refined craft involving combinations and variations of basic elements. Like the visual art of a master painter like Jan Vermeer, effective book reviews begin with skillfully organized combinations and variations of elements that when integrated are essential in creative synthesis. Book reviews offer more freedom than most other technical writing for you to pursue synthesis in your literary craft. Pursue that creative synthesis, as you seek art.

\section{Literature Cited}

Drewry, John E. 1945. Book reviewing. The Writer Inc., Boston, Mass. 228 p.

Strunk, William Jr., and E. B. White. 1959. The elements of style. Macmillan, New York, N.Y. 71 p.

Thomson, Ashley. 1991. How to review a book. Can Lib. J. 48:416-418. 